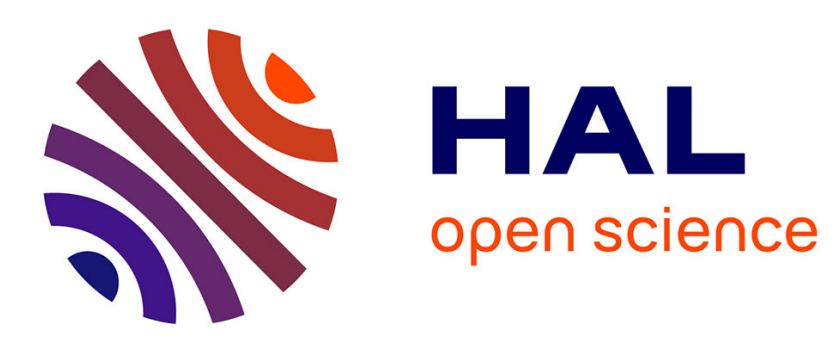

\title{
Innovative complexity in the pronominal paradigm of Mojeño: a result of contact? \\ F. Rose
}

\section{To cite this version:}

F. Rose. Innovative complexity in the pronominal paradigm of Mojeño: a result of contact?. Francesco Gardani; Peter Arkadiev; Nino Amiridze. Borrowed morphology, De Gruyter Mouton, pp.241-267, 2015. hal-01200732

\section{HAL Id: hal-01200732 \\ https://hal.science/hal-01200732}

Submitted on 17 Sep 2015

HAL is a multi-disciplinary open access archive for the deposit and dissemination of scientific research documents, whether they are published or not. The documents may come from teaching and research institutions in France or abroad, or from public or private research centers.
L'archive ouverte pluridisciplinaire HAL, est destinée au dépôt et à la diffusion de documents scientifiques de niveau recherche, publiés ou non, émanant des établissements d'enseignement et de recherche français ou étrangers, des laboratoires publics ou privés. 
Françoise Rose

\section{Innovative complexity in the pronominal paradigm of Mojeño: a result of contact?}

\section{Introduction}

This paper deals with the pronominal paradigm of Mojeño, an Arawak language spoken in Bolivia. It is a rich paradigm, with seven different third person categories, and is rather uncommon in indexing the gender of the speaker. We raise the question of the genesis of this pronominal paradigm, and pursue this at the comparative, internal, and areal levels. It is a contribution, in methodological terms, to the necessity of contact linguistics to study a contact situation in detail and balance all possible factors that may have led to change.

Section 2 first shows that pronominal forms are found as independent pronouns, articles, demonstratives, person prefixes and suffixes on verbs and nouns. It then argues that these different sets of morphemes can be considered to be derived from the same pronominal paradigm, first relying on morphophonemic evidence, then by describing the common semantic distinctions found in the various sets of person markers. The pronominal paradigm is particularly rich in third person categories: it has, on the one hand, an unspecified third person form, and, on the other hand, a set of forms distinguished according to humanness, number, gender of the referent, and gender of the speaker (Rose 2013d). The combination of these different forms results in a complex pronominal system, with a typologically remarkable third person subject indexation system on verbs, conditioned by co-arguments (Rose 2011).

Section 3 shows that, while most Mojeño pronominal forms can be traced back to Proto-Arawak, some third person forms (and the category they embody) do not easily compare with reconstructions (Payne 1987) or data in sister languages (Danielsen 2011), namely the non-human form, the distinction depending on the gender of the speaker and maybe also the unspecified third person subject form. There is little internal data enlightening the innovation hypothesis. Some possible internal developments are nevertheless discussed.

Finally, Section 4 explores the idea that the innovative forms and/or categories may have arisen through contact. It is traditionally asserted that personal markers are among the most stable elements of the language's morphology (Heine and Song 2010), but cases of borrowed pronouns are attested (see, e.g., Wallace 1983). Moreover, Mojeño has a very rich contact history. Three processes are considered: borrowing of categories, borrowing of forms, and creation of 
categories via multiple sources. This latter process has been an explanation for the distinction between male and female speech in Island Carib (Taylor and Hoff 1980). Unfortunately, no source language is identifiable with absolute certainty for the pronominal categories/forms under study.

\section{The Mojeño pronominal paradigm}

The Mojeño language spoken in present-day Bolivia has been documented since the early 18th century (Marbán 1702) - to date, with the descriptions of its two extant dialects: Ignaciano (Olza Zubiri et al. 2002) and Trinitario (Rose 2011b, in press). This paper is based on historical data from Marbán (1702), Ignaciano data from Olza Zubiri et al. (2002), and my own corpus of Trinitario, recorded in the field between 2005 and 2010.

This section presents the Mojeño pronominal paradigm in a "synchronic" perspective, considering a single system for both 18th-century Mojeño and the modern dialects. The pronominal paradigm and its use are rather stable over time, from the earlier descriptions by Marbán (thereon called Old Mojeño) to the modern ones. The major changes between Old Mojeño and the modern dialects are: firstly, the extension of the paradigm in the article position (2.1); secondly, the reduced phonological forms and multiple allomorphs in the Trinitario dialect because of a pervasive vowel deletion process (3.3); and, thirdly, the optionality of the 3sG subject prefix $t i$ - in the Ignaciano dialect (2.4). Sections 3 and 4 will cover the older diachronic evolutions leading to this system.

In Section 2.1, I first list the various sets of person markers with their functions; and then I show how these can be reduced to a single pronominal paradigm on both formal (2.2) and semantic (2.3) grounds. Finally, Section 2.4 details the complex use of the paradigm for the encoding of the third person subject.

\subsection{The sets and functions of the person markers}

Mojeño person markers are used with various functions: as independent pronouns (1), demonstrative roots (2), and affixes used on verbs and nouns (3). They also have extended to the article function in the modern dialects (4), a use that was not attested in Marbán's grammar nor in his catechism (Marbán [1702] 1975).

This diversity of functions is illustrated below with the third person human singular feminine category, encoded with the $s u$ form. Examples are taken from the modern Ignaciano dialect (Olza Zubiri et al. 2002: 16, 855, 431, 229). Moreover, 
the non-human article to can introduce subordinate clauses, with or without an overt nominalizer on their verb (Rose 2011a).

(1) esu ti-cajari

(Mojeño Ignaciano)

3F 3-be.pregnant

'She is pregnant.'

(2) esu su-na esena ichasi-ha-pa

3F F-DEM.DIS woman old-CLF-PERF

'That woman is already old.'

(3) ti-cati eta su-ámi

3-hurt ART.3NH 3F-stomach

'Her stomach hurts.'

(4) ichape-he-pa su esena

big-CLF-PERF 3F woman

'The woman is big-bellied.'

Prefixes occur on nouns to refer to their possessor (3). They also occur on transitive verbs (5), referring to their agentive argument, and on intransitive verbs, active (6) or stative (7), referring to their unique argument. However, the third person prefixes with specific semantics (such as su for third person human singular feminine) are usually replaced by a non-specific third person prefix ti- on intransitive verbs, as in (6) and (7), as well as on transitive verbs, as in (8), in some particular morphological, syntactic and discourse contexts. This differential third person subject marking system will be described in Section 2.4. The following examples are taken from Olza Zubiri et al. (2002: 90, 56, 71, 90).

(5) su-imaha ena

(Mojeño Ignaciano)

3F-see 3PL

'She sees them.'

(6) esu t-ijuru-ca

3F 3-grow-ACT

'She grows.'

(7) esu ti-úri

3F 3-be.good

'She is good.'

(8) esu t-ímaha-havi

3F 3-see-1PL

'She sees us.' 
Suffixes index the patientive argument of a transitive verb (9), or the unique argument of both nominal predicates (10) and adjectival predicates (11). As there is no third person suffix to mark a third person patient, examples are given in the 1SG (Olza Zubiri et al. 2002: 89, 63, 83). Suffixes have quite a comparable form with prefixes, as discussed below in Section 2.2 and illustrated in Table 1.

(9) piti p-imaha-nu

2SG 2SG-see-1SG

'You see me.'

(10) achane-nu.

person-1sG

'I am a person.'

(11) túme-nu

strong-1SG

'I am strong, valiant.'

The following sections show that the sets of person markers used in the various functions presented here can be considered to form a single paradigm, on both formal and semantic grounds.

Tab. 1: Old Mojeño's sets of person markers and the basic pronominal paradigm

\begin{tabular}{|c|c|c|c|c|c|}
\hline & Pronouns, articles ${ }^{1}$ & DEM root & Prefixes & Suffixes & Basic paradigm \\
\hline $1 \mathrm{SG}$ & nuti & & nu- & $-n u$ & nu \\
\hline $2 \mathrm{SG}$ & piti & & pi- & $-v i$ & pi \\
\hline $1 \mathrm{PL}$ & viti & & $v i-$ & $-a v i$ & vi \\
\hline $2 \mathrm{PL}$ & eti & & $e-$ & $-e^{2}$ & $e$ \\
\hline $3 M^{\lambda}$ & ema & $m a$ & $m a-$ & & $m a$ \\
\hline $3 M_{+}$ & $e \tilde{n} i$ & $\tilde{n} i$ & $\tilde{n} i-$ & & $\tilde{n} i$ \\
\hline $3 \mathrm{~F}$ & esu & su & su- & & su \\
\hline $3 \mathrm{PL}$ & eno & no & na- & & no \\
\hline $3 \mathrm{NH}$ & eto & jo $\sim$ to & ta- & & to \\
\hline 3 & & & $t i$ - (on verbs only) & & $t i$ \\
\hline 'other' & & & opo- (on nouns only) & & opo \\
\hline
\end{tabular}

1 Articles are attested only in the modern varieties. In Ignaciano, their form is similar to those of the third person pronouns, with frequent apocope of the initial /e/ (Olza Zubiri et al. 2002:11). In Trinitario, their form is always CV, without initial /e/.

2 The glottal stop is never transcribed in Marbán's work. I reconstruct it from data of the modern dialects. 


\subsection{A single pronominal paradigm: formal similarity}

Table 1 shows the various sets involving person markers (based on data from Old Mojeño). The $\delta$ and $q$ symbols refer to the gender of the speaker. Indexicality of the gender of the speaker is discussed in Section 2.3. The similarity of the pronominal sets is self-evident. Very few morphophonemic rules allow to posit a unique pronominal paradigm. This paradigm is given in boldface in the last column of Table 1.

From this basic pronominal paradigm, most of the forms of the various sets can be derived by regular processes: the same CV paradigm is used almost without modification in the prefix and suffix positions. Free pronouns are built with a formative $-t i$ on first and second person pronominal forms, and a formative $e$-for third person forms (except underivable $t i$ and opo). The articles have the same form as third person pronouns in Ignaciano. Several sets of demonstratives are built on this personal paradigm with a distance suffix and an optional po- prefix, as in po-su-ka (DEM-F-PROX) 'this one here' (feminine).

A few deviations from the same basic personal paradigm must be noted:

a The correspondence of the 2SG forms vi with the 2SG pi suffix. The former probably results from a lenition process.

b The absence of third person suffixes to index a third person patientive argument, a cross-linguistically common gap.

c The non-human form jo (found in the presently extant dialects and in Old Mojeño) rather than to (found as an option in Old Mojeño only (20)) in the demonstratives.

$\mathrm{d}$ The restriction in use of the non-specific third person marker $t i$ - in the prefix position on verbs, and of 'other' opo- on nouns.

e Alternation of /o/ and /a/ in the pronouns, articles, demonstratives, and prefixes in the forms for $3 \mathrm{NH}$ and 3PL. ${ }^{3}$

The synchronic similarity of these various pronominal sets points towards a common origin. As Siewierska (2004: xv) underlines, "different instantiations of the category of person are best viewed as defining both a diachronic and a synchronic cline in regard to their formal and functional properties." It

3 In the Ignaciano dialect, the $0 /$ a distinction has been neutralized. The /o/ phoneme is not attested anymore. For this reason, the non-human and plural markers do not show the o/a alternation and the vowels of the prefix "other" and the suffix for 1PL are /a/ in Ignaciano. 
is generally supposed that the different sets of person markers in a language may develop from a set of independent pronouns and/or demonstratives, some becoming bound as affixes. In Mojeño, we also hypothesize that a set of ProtoMojeño independent pronouns is at the origin of the several sets of person markers. Nevertheless, these Proto-Mojeño independent pronouns are not identical to present independent or demonstrative pronouns, but should most likely be reconstructed as independent forms similar to the basic paradigm (final column of Table 1). They very likely are the diachronic source for the other sets given in Table 1, via derivation for the free pronouns and the demonstratives, via cliticization and affixation for the affixes, and via extension for the articles (Rose 2013a).

Even though the basic pronominal paradigm is shared by the Ignaciano and Trinitario dialects, the pronominal markers of the two dialects differ in form, essentially because of the vowel deletion rule of Trinitario (cf. 3.3). Illustrative examples in this paper thus contain forms that differ from those of Table 1. Appendix A presents all the pronominal forms of Old Mojeño, Mojeño Ignaciano and Mojeño Trinitario.

\subsection{A single pronominal paradigm: semantic categories}

From the semantic point of view, the various pronominal sets also show the same categorization, with first and second person forms showing a number distinction, and five shared categories for third person. This coherence of the various sets makes it possible to consider the single basic paradigm offered in the final column of Table 1. Only three deviations are found:

i. An unspecified third person marker ti-is found only as a verb prefix.

ii. The "other" index is found only as a prefix on nouns. As this prefix is very likely a reflex from the Proto-Arawak impersonal (see Table 2), it will not be discussed further here.

iii. The number distinction within the non-human category plays a role only in the demonstrative set of the Trinitario dialect. The plural non-human form is a homonym of the human singular masculine with male speaker, viz. ma.

4 The glosses of pronominal forms are simplified in that $M$ or $F$ imply human and singular, and $\mathrm{PL}$ implies human. Gender of the speaker is not specified in the $M$ gloss. 


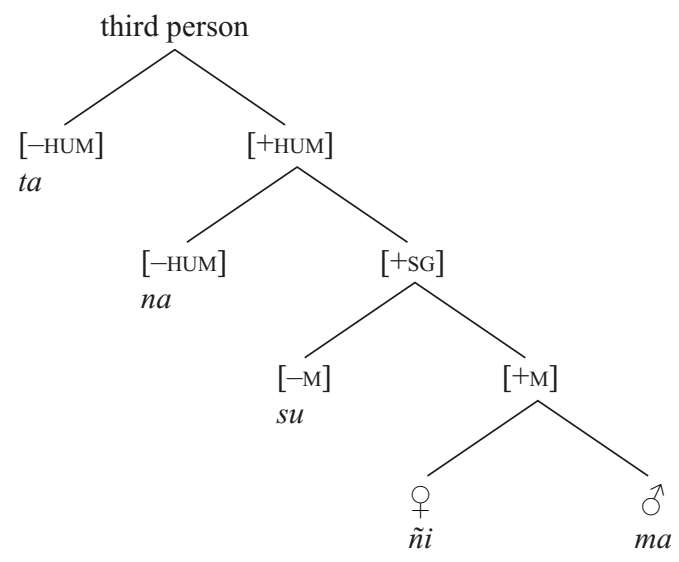

Fig. 1: Semantic sub-categorization of third person.

The rich third person sub-system is interesting, in that its sub-categorization is asymmetric, with many distinctions specific to a sub-category and neutralized everywhere else (Figure 1). ${ }^{4}$

Distinctions within pronominal paradigms depending on the gender of the speaker are rarely discussed in the literature (Fleming 2012; Rose 2013b). Gender indexicality is indeed a rather little-known phenomenon by which linguistic items (phonological, morphological, or lexical) point to the gender of the speech act participants (Silverstein 1985). It differs from grammatical gender in that first, it does not deal with the gender of the referent but with that of a speech act participant, and second, the speech act participant is not part of the propositional content. An example of addressee-gender indexicality is the Basque "allocutivity" system (Alberdi 1995). Speaker gender indexicality in Mojeño is exemplified below with the Trinitario masculine articles $\tilde{n} i$ and $m a$ that both refer to a masculine referent 'the.M' (and can be used to refer to exactly the same person) but index a female and a male speaker, respectively (see Rose 2013d for details on Mojeño gender indexicality).
(12) a) $\tilde{n} i \quad$ 'chane
$3 \mathrm{M}_{\text {}}$ person
'the man'?
b) $m a \quad$ 'chane
$3 \mathrm{M}^{\lambda} \quad$ person
'the man' $\widehat{O}$

(Mojeño Trinitario) 


\subsection{Complexity of third person subject marking}

Mojeño indexes $A / S_{a} / S_{0}$ of verbal predicates in the prefix slot, as in (5), (6), and (7) respectively, and $\mathrm{O}$ in the suffix slot, as in (9). It indexes the $\mathrm{S}$ of non-verbal predicates in the suffix slot as well, as in (10) and (11). Mojeño can be considered a split-S language when comparing verbal and non-verbal intransitive predicates (see Danielsen and Granadillo 2008, for a comparable argument concerning Baure and Kurripako).

Recall that there is one marker that does not perfectly fit the pronominal paradigm: $t i$ - is found only as a prefix on verbs only, not on nouns. It is missing in the demonstrative, the article, and the free pronoun paradigms. Moreover, it covers the same range of referents as the third person set described above: $m a$, $\tilde{n} i, s u, t a, n a$. In fact, this marker distinguishes neither humanness, nor number, nor gender of the referents or of the speaker, as the different translations of the Trinitario example (13) illustrates.
esu/ema/eñi/eto/eno
t-epeno-(m)-po
$3 \mathrm{~F} / 3 \mathrm{M}{ }^{\top} / 3 \mathrm{M}+/ 3 \mathrm{NH} / 3 \mathrm{PL}$
3-die-(PL)-PERF
'she/he/it/they died'

(Mojeño Trinitario)

This implies the selection of either $t i$ - or one of the specified prefixes ( $m a-, \tilde{n} i-$, $s u-, t a-, n a-)$ for a third person subject. The result is a unique and complex system of S/A marking, which forms a cross-linguistically unknown indexation system (Rose 2011b). The distribution of the third person subject markers depends essentially on verbal transitivity and the person of its object: it forms a co-argument conditioned agreement system (Witzlack-Makarevich et al. 2011). The system is described below and exemplified with Trinitario clauses.

A marker of the $m a-, \tilde{n} i-, s^{-}, t a-, n a-s e t$ is used to express a third person subject on transitive verbs with a third person object (14). As noun phrases are not obligatorily overt, the same verb form could stand on its own as a full sentence.

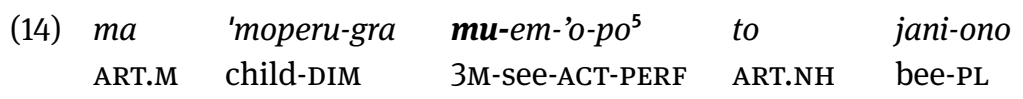

'The little boy saw the bees.'

The $t i$ - prefix is used for a third person subject on intransitive verbs (active (6), stative (7)) and on transitive verbs with a first or second person object, itself

5 When $m a$ - is prefixed to a root with initial /e/ or /i/, this sequence is realized as /mwe/, written <mue>. 
indexed on the verb with a suffix (15). It is optional on consonant-initial verb stems in Ignaciano, so that the verb can stand without prefix (Olza Zubiri et al. 2002: 478).

(15) ty-okpo-wokovi ${ }^{6}$

3-meet-1PL

'He/she/it/they meet us.'

So basically a third person subject is marked on transitive verbs with $t i$ - when the object is a first or a second person, and with markers of the $m a,-\tilde{n} i^{-}, s^{-}, t a-, n a-$ set when the object is a third person. There are deviations from this syntactic rule, on semantic and discourse grounds (see Rose 2011b, for details). To my knowledge, no such system is attested in the rest of the Arawak family nor in the south-western Amazonian region (nor in the world, actually). This uncommon and complex indexation system on verbs results from the use of the ti marker in Mojeño.

Section 2 has presented the personal paradigm of Mojeño. It has argued on formal and semantic grounds that a single paradigm can be considered to be at the basis of all the sets of person markers (pronouns, articles, demonstratives and affixes). It has insisted on the fact that the paradigm is particularly rich regarding third person encoding, and that this leads to a complex system of third person subject encoding on verbs.

\section{The Mojeño pronominal paradigm as innovative complexity within Arawak}

\subsection{Reconstructions of Proto-Arawak and Proto-Southern Arawak}

Reconstructions of the Proto-Arawak pronominal system have been offered by Payne (1987) and Aikhenvald (1999: 88). ${ }^{7}$ The suggested forms are given in Table 2. Reconstructed forms without hyphens are given as the proto-forms of both prefixes and suffixes.

\footnotetext{
6 In the Trinitario dialect, the -ovi 1PL suffix (the reflex of Old Mojeño -havi) often combines with a PL suffix -woko.

7 The suggested proto-forms differ very little. The differences basically concern the first person with two variants $n u-\sim$ ta- as prefixes and two other $-n a \sim-t e$ as suffixes and the third person singular with $\mathrm{V}$ allomorphs: $r i \sim i \mathrm{M}$, thu $\sim u \mathrm{~F}$ according to Aikhenvald.
} 
Tab.2: Proto-Arawak person affixes based on Payne (1987: 62-63) and Aikhenvald (1999: 88)

\begin{tabular}{llllllllll}
\hline 1SG & 2SG & 1PL & 2PL & 3SG.M & 3SG.F & 3PL & IMP & A/Sa & S $_{0} / \mathbf{0}$ \\
\hline${ }^{*} n u$ & ${ }^{*} p i$ & ${ }^{*} w a$ & ${ }^{*} x i$ & ${ }^{*} r i$ & ${ }^{*} t u$ & ${ }^{*} n a$ & ${ }^{*} p a-$ & ${ }^{*} i-\sim a-$ & $-n i$ \\
\hline
\end{tabular}

The first seven columns show a set that was reconstructed for both person prefixes on nouns and verbs, and person suffixes on verbs. Every reconstruction consists of a CV form. Payne (1987: 61) notes that "the forms for 1sG, 2SG, 1PL and 2PL are the most stable" and that in various languages, the prefixes show an allomorph without vowel used when preceding a vowel initial stem. The Arawak pronominal systems usually distinguish two genders in the singular only, typically feminine and non-feminine (Aikhenvald 2002: 516). Aikhenvald states that personal pronouns in the Arawak languages regularly consist of a cross-referencing prefix plus an emphatic one-syllable particle, and that they can often be used as proximate demonstratives, and as definite articles with nouns (Aikhenvald 1999: 85). The proto-forms of the last three columns were suggested by Aikhenvald only. Two of these are instantiated by prefixes only, the impersonal * $p a$ - used for a generalized, unspecified referent ("someone"), and the non-focused $\mathrm{A} / \mathrm{S}_{\mathrm{A}}$ that neutralizes person/gender and number. ${ }^{8}$ The third is a dummy suffix for So/O that is not relevant for the present study.

A preliminary reconstruction of Proto-Southern Arawak was offered in Danielsen (2011), a comparative study of the personal paradigm in Southern Arawak languages, including Paunaka, Mojeño, Terêna, the Apurinã/Piro/Iñapari subgroup, the Campan languages, Amuesha and Chamicuro. It suggests a system with a primary distinction between singular and plural in the third person, and a secondary distinction between masculine, feminine and unspecified in the singular $^{9}$ (Table 3). The masculine/feminine distinction ${ }^{\star} r i{ }^{\star} r u$ is reconstructed as in Proto-Arawak, even though it is attested only in three languages: Apurinã, Ashéninka/Ashaninka, and Baure (with reversed meanings: $r$ for '3sG.F' and $r o$ for '3sG.M'). This is a clear evidence that in this branch as well, the expression of third person is unstable.

8 It is (somewhat misleadingly) called indefinite in Aikhenvald (1995) because it is interpreted as indefinite in specific contexts (i.e. in interrogative sentences and on obligatorily possessed nouns with an unknown possessor).

9 Danielsen (2011) classifies ti- as a singular third person marker. It is in fact unmarked with respect to number in both Mojeño and Paunaka. 
Tab. 3: Proto-Southern Arawak person markers (adapted from Danielsen 2011: 513)

\begin{tabular}{llllllll}
\hline 1SG & 2SG & 1PL & 2PL & 3SG.M & 3SG.F & 3PL & 3 \\
\hline${ }^{\star} n u$ & ${ }^{\star} p i$ & ${ }^{*} w(a)$ & ${ }^{\star} h i /{ }^{\star} y i$ & ${ }^{{ }} r i$ & ${ }^{{ }} r u$ & ${ }^{{ }} n a$ & ${ }^{{ }} t i$ \\
\hline
\end{tabular}

The only important divergence from the Proto-Arawak system is the reconstruction of the unspecified third person. It is, however, crucial to note that it has been reconstructed on the basis of two languages only: Mojeño and Paunaka. Paunaka shows a two-way marking for third person ( $t i-\mathrm{vs.}$ chi- $\sim$ chÿ- $)^{10}$ that is reminiscent of the Mojeño alternation between non-specified third person $t i$ - and the set of specified third person prefixes. The main difference is that Paunaka chi-is unspecified semantically for gender and number. The facts leads us to think that $t i$ is a shared innovation of Mojeño and Paunaka.

\subsection{Innovations in Mojeño}

Table 4 compares the pronominal paradigm of Old Mojeño (Marbán 1702: 5-13) with the available reconstructions of Proto-Arawak (Payne 1987; Aikhenvald 1999: 88) and Proto-Southern Arawak (Danielsen 2011: 513).

Three innovations have affected the pronominal paradigm of Mojeño (in bold in Table 4). All three concern precisely the expression of third person, in line with the following assertion on the Arawak pronominal systems: "the third person forms have undergone the most extensive changes or losses" (Payne 1987: 64). Arawak languages indeed generally display a simple categorization of third person prefixes (with masculine, feminine and plural only). Mojeño has undergone the following changes:

Tab. 4: Comparison of the pronominal paradigm of Proto-Arawak (PA), Proto-Southern Arawak (PSA) and Mojeño $(\mathrm{OM})^{11}$

\begin{tabular}{|c|c|c|c|c|c|c|c|c|c|}
\hline & $1 \mathrm{SG}$ & 2SG & $1 \mathrm{PL}$ & $2 \mathrm{PL}$ & 3SG.M & 3SG.F & 3PL & $3 N H$ & 3 \\
\hline PA & ${ }^{\star} n u$ & ${ }^{\star} p i$ & ${ }^{*} w a$ & ${ }^{\star} x i$ & ${ }^{\star}$ ri & ${ }^{*}$ tu & *na & & \\
\hline PSA & ${ }^{\star} n u$ & ${ }^{*} p i$ & ${ }^{*} w a$ & ${ }^{*} h i /{ }^{*} y i$ & ${ }^{*} r i$ & ${ }^{*} r u$ & ${ }^{\star} n a$ & & ${ }^{*} t i-$ \\
\hline $\mathrm{OM}$ & $n u$ & pi & $v i$ & $e$ & $\begin{array}{l}\tilde{\boldsymbol{n} i}+{ }_{+} \\
\boldsymbol{m a} \partial\end{array}$ & su & no & $\begin{array}{l}\text { to } \\
\text { jo DEM }\end{array}$ & $t i-$ \\
\hline
\end{tabular}

$10<\ddot{y}>$ stands for a high central vowel.

11 This table does not include the three proto-forms reconstructed by Aikhenvald only (see the last three columns of Table 2). Their possible reflexes are not relevant for the present study. 
i. Introduction of a distinction according to the gender of the speaker for third person masculine. Island Carib and its offspring Garifuna, two Arawak languages, show a male versus female speech distinction (de Pury 2001; Taylor and Hoff 1980). It is nevertheless not inherited from Proto-Arawak, but is a result of the integration of a great number of Carib items in an Arawak language (cf. 4.3). In Mojeño, the $\delta$ form $m a$ has obviously been added. The $q$ form $\tilde{n} i$ could also be an addition, but is more probably a nasalized reflex of Proto-Arawak ${ }^{\star} r{ }^{12}$

ii. Introduction of a non-human third person category with the forms to and, specifically in the demonstratives, jo. Both the form and meaning of to can be considered innovative. They could also logically result from a split from the Proto-Arawak form $3 \mathrm{SG} .{ }^{\star}{ }^{\star} t u$, the feminine category being the unmarked category in the Caribbean Arawak languages, though this would imply a change from / $\mathrm{t} /$ to / $\mathrm{s} /$ before $/ \mathrm{u} /$ but not before /o/. Interestingly, Baure also has a marker to, used as an article with no specification of gender and number, and as a plural demonstrative. It is in competition with the singular feminine demonstrative $t i$, in the article function. Remarkably, Baure to occurs frequently in cleft or relative clauses and before nominalized verbs (Danielsen 2007: 312), in a comparable way with the use of Mojeño to in subordinate clauses mentioned in Section 2.1. In some apparently exceptional examples, Baure to and $t i$ were also found as subject clitics on the verb, with a comparable distribution of $t a$ - and $t i$ - in Mojeño. The origin of non-human jo is unknown, though it could derive from impersonal * pha.

iii. Introduction or development of a non-specified third person category and form $t i$-. The marker $t i$ - is particular in being restricted to the prefix position on verbs. It is very probably a shared innovation with Paunaka (cf. Section 3.1). Some similarities in use can be noted with the non-focused subject prefix $i$-/ $a$ - of Northern Arawak languages. It is interesting to note that discourse factors can interfere with the basic indexing of the subject in Mojeño as well as in the Northern Arawak languages (Rose 2011b). On the basis of comparative data, the genesis of Mojeño and Paunaka ti- remains unclear, as well as that of Mojeño ma, to and jo.

\subsection{Internal evidence for innovation?}

Data from Mojeño Trinitario is apparently divergent in its surface realization, because of a high allomorphic variation resulting from a pervasive vowel dele-

12 The form $\tilde{n} i$ - is comparable to the masculine markers of Guajiro $n \dot{n-} \sim n u-\sim n i-$ (Payne 1987: 82), Warekena ni- (Aikhenvald 1999: 88), or to the third person (neutralizing gender and number) in- in Yawalapiti (Mujica 1992: 60). There is yet no independent evidence for the development of $/ \mathrm{r} /$ into $/ \tilde{\mathrm{n}} /$ in the Mojeño language. 
tion rule that developed in this dialect only (Rose 2008, 2014) and affects among others the person affixes.

In Old Mojeño, "two adjacent consonants are not attested, or only very rarely" (Marbán 1702: 1). In Trinitario, vowel deletion is quasi-systematic on stems of three syllables or more. ${ }^{13}$ It generally affects all odd-numbered syllables starting with the first, and excepting the final one. This results in frequent and unexpected word-internal consonant sequences, but these remain heterosyllabic (except word-initially). Examples (16) and (17) illustrate this, on an underlying trisyllabic Trinitario noun. Very often, phonological rules modify these consonant sequences, creating various alternate forms for most morphemes. Ex. (17) also shows that vowel deletion affects pronominal prefixes, which are reduced to a single consonant. In this section, examples are presented with the surface realization in the first line and the underlying form in the second line. The straight underlining in the underlying form indicates vowels to be deleted (information on the quality of the deleted vowel may be irretrievable). The pronominal suffixes are affected only when followed by other suffixes (18). In word-final position, they are not affected (cf. (9) to (11)). ${ }^{14}$

(16) pku.re

(Mojeño Trinitario)

pa.ku.re

'canoe'

(17) spok.re

su-pa.ku.re

3F-canoe

'her canoe'

(18) tajina ñag.gion.ño.re

tajina ñi-a.gV.gio-nu-yo.re

nothing 3M-do.sth.to-1sG-FUT

'He is not going to do anything to me.'

Importantly, a subset of third person prefixes ( $m a-$, $\tilde{n} i^{-}, t a-$ and $\left.n a-\right)$ is transparent to the otherwise regular vowel deletion of the word-initial syllable: their vowel should be deleted but is maintained and still, vowel deletion affects every oddnumbered syllable to its right, except the final one (19). Dotted underlining in the underlying form indicates the vowels that are transparent to vowel deletion.

13 Some irregularly-stressed roots resist vowel deletion. The initial vowel of disyllabic roots is not deleted when the root is word-initial.

14 Free pronouns and articles are not affected because they are disyllabic or monosyllabic words (e.g. nuti 'l', to 'ART.NH'). The pronominal base of demonstratives is not affected because it is always in the second syllable of the demonstrative ( $p_{-}$-su-ka 'DEM.F.PRox'). 
(19) na.pok.re

na-pa.ku.re

3PL-canoe

'Their canoe'

Two explanations can be considered. A first possible explanation relies on the hypothesis of $m a$ - and $t a$ - being a later addition to an existing paradigm. From Marbán's work, we know that $t a$ - and $m a$ - entered the system before the prosodic rule of vowel deletion was settled in Trinitario, but a possibility is that their recent introduction into the language would have preserved their vowels. The stems they combine with show the same vowel deletion pattern as with other prefixes, so that $m a$ - and $t a$ - can be considered as neither extrametrical, nor external to the prosodic word. This hypothesis must nevertheless be dismissed because $\tilde{n} i$ - and $m a$ - are also transparent to vowel deletion although they are inherited.

A second possible explanation is phonological. While ñi- would have resisted vowel deletion because / $\tilde{\mathrm{n}} /$ is not allowed as the first element of a complex onset, the three prefixes $m a-$, $t a-$, and $n a$ - would have resisted on the basis of their sharing an /a/. The problem with this hypothesis is that there is no other evidence of an intrinsic resistance of /a/ to vowel deletion. ${ }^{15}$ Cross-linguistically high vowels are shorter in duration than lower vowels. ${ }^{16}$ This would make rather high vowels more subject to deletion than low vowels.

In the end, the particular behavior of some person prefixes in the vowel deletion process is not an evidence for their recent genesis.

\subsection{Internal development}

Person markers are traditionally considered to be diachronically fairly stable (Wallace 1983). Yet pronominal paradigms are subject to change via renewal (encoding modification of already existing categories) or innovation of new categories. This paper is concerned with the innovation of categories, more specifically the innovation of the non-human category, the male/female speaker distinction and maybe the unspecified third person category, in Mojeño.

Sources for new independent pronouns are listed in Siewierska (2004: 247261) and Heine and Song (2011). Major sources for new third person pronouns are: demonstratives; nouns (primarily generic nouns for human beings, such as

15 There is, conversely, evidence that / $/$ / and / $u$ / are particularly sensitive to vowel deletion in Trinitario. Classifiers are normally opaque to vowel deletion, but the rare attested cases of vowel deletion in classifiers affect an /i/ or / $\mathrm{u} /$.

16 High vowels are also prone to devoicing. 
"person, body, etc.", but also terms for kinship, social status and professions); intensifiers, reflexives and identitives such as "self".

Mojeño data do not provide evident nominal or intensifier-type sources for any of the supposed non-inherited pronouns. Of these, $m a$ and ta show some demonstrative correspondent. However, as explained in Section 2.1, the Mojeño demonstratives are regularly derived from the basic paradigm with an optional po- prefix and a distance suffix (20). It is known that beside being a frequent source for pronouns, demonstratives can conversely be derived from pronouns (Bhat 2004: 133). This is what is postulated for Mojeño.

$\begin{array}{ll}\text { po-to-ka } & \sim \\ \text { DEM-3NH-PROX } & \text { DEM-jo-ka } \\ \text { 'this' } & \end{array}$

(Old Mojeño, Marbán 1702)

Within the demonstratives, the non-human person base was either to or jo in Old Mojeño (with only to corresponding to the basic person paradigm). Only $j V$ is found in Ignaciano, while in Trinitario jo is used for singular referent and $m a$ for plural ones. It is not clear whether the jo/ma forms are younger or older than the to forms. Their sources are not clear either.

Just as the Mojeño demonstrative forms are derived from the basic paradigm, it is clear that independent pronouns, too, are built on the basic paradigm in Mojeño, as well as in Arawak languages in general (cf. Section 3.1). Mojeño free pronouns are derived with the adjunction of extra material to the basic paradigm, -ti on first and second person forms and $e$ - on third person forms. Danielsen notes that $t i(\sim t i)$ is a formative suffixed on the $\mathrm{CV}$ pronominal form to constitute first and second person independent pronouns in several Southern Arawak languages. Siewierska (2004: 254) provides, as a source for the renewal of independent pronouns, the development of independent pronouns from dependent person markers. Independent forms can in fact be built on the dependent forms plus a generic pronominal root ("person", "body" or "self", etc.), a deictic form or an emphatic form. The hypothesis that $t i$ could originally be a free deictic form is interesting in that respect, in that it could also account for the homonymous unspecified third person prefix ti-. Recall that Baure, a close neighbor, shows a feminine demonstrative $t i$ (Danielsen 2011: 501). ${ }^{17}$

Finally, a last hypothesis of internal development can be put forward. The non-human person marker (e)to is very similar to the numeral for "one"

17 An extra argument offered by Danielsen is that Baure speakers occasionally suggested in elicitation sessions free personal pronouns formed of a CV personal form and a demonstrative, as roteč instead of roti' '3SG.M' (Danielsen 2007: 319). 
(eto+classifier as in (21)). Interestingly, Paunaka shows a numeral "one" built on chy- (the form alternating with $t i$ - in the verbal system), followed by a classifier and another chy found on all numerals (22).

(21) eto-pi

(Old Mojeño, Marbán 1702)

one-CLF:long_flex

'one whip (or anything long, narrow and flexible)'

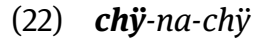

(Paunaka, Lena Terhart, p.c.)

one-CLF-NUM?

'one'

The numeral "one" is a frequent source for indefinite articles cross-linguistically (Greenberg 1978; Heine and Kuteva 2002, 2006). If this were also the case in Mojeño (where articles are unmarked for definiteness), the emergence of a non-human article would have created a further category in the basic paradigm, which then extended to all other functions of the person markers. Interestingly the numeral eto is not easily traced from Proto-Arawak * $b a$ 'one' (Payne 1991: 414), so that this hypothetic internal development would be based on either some other internal development of the numeral, or on its previous borrowing.

In Section 3, I have argued that the Mojeño system probably shows three innovations. These are:

i. The introduction of a distinction according to the gender of the speaker for the third person masculine.

ii. The introduction of a non-human third person category and form to.

iii. The introduction or development of a non-specified third person category and form $t i$.

The few (and weak) hypotheses made about internal development are summarized below:

- Unspecified ti- could be an innovation shared with Paunaka, maybe on the basis of a deictic form $t i$, also used to form independent pronouns in several South Arawak languages.

- The non-human marker to may be related to a non-inherited numeral "one" in Mojeño and Paunaka (and to the Baure article).

We will now turn to the contact-induced hypothesis relating to the Mojeño pronominal paradigm. 


\section{Influence of contact in the innovation of pronominal forms and categories}

As pronouns are generally rather stable diachronically (Heine and Song 2010; Wallace 1983), a common thought is that they are very unlikely to be borrowed (Dixon 1997: 22; Matras 2009: 203). Yet many examples of individual pronominal borrowings are attested, mostly regarding the inclusive/exclusive distinction or concerning the languages of South-East Asia, where social deixis is very important (Siewierska 2004: 274-277; Wallace 1983). Other types of examples are also punctually attested (Matras 2009: 203-208; Mithun 2012: 203-208; Thomason and Everett 2001). Pronouns are in fact borrowable.

Siewierska (2004: 273-281) lists four possible externally driven change regarding person markers. I will add a fifth one, on which I will elaborate below:

i. Borrowing of a form

ii. Borrowing of a category

iii. Borrowing of a system

iv. Loss of person markers

v. Complexification of the paradigm via language mixture

The contact history of Mojeño makes it conceivable that the innovations in the pronominal system have resulted from the contact with other languages. Mojeño has a very rich contact history. The Jesuits started their activity in the region called "Mojos plains" in the 1660s. A remarkable diversity of languages was then spoken - 39 were reported in the early 18th century. Unfortunately, there is very little knowledge about the period preceding the Jesuits missions, because of a lack of archeological and ethno-historical studies. Mojeño was the lengua general of the Mojos missions during the Jesuit period 1669-1767. Saito (2009) provides an analysis of the Jesuit language policy, along the following lines. The Jesuits were following the colonization policy called "reduction": they brought together various indigenous people and offered them Mojeño as a lengua general, i.e. a lingua franca used for collective life in the missions, especially for evangelization. A grammar of the language and a catechism in the language were written by a Jesuit priest (Marbán [1702] 1975) and the children were taught the language in school. Native languages were still used outside of church, and Spanish was little used. Mojeño was chosen as a lengua general in the first four missions, created from 1682 on, because the majority of the inhabitants were Mojeño speakers. ${ }^{18}$

18 Other missions were created in the Mojos region also beyond the Mojeño's territory. There, other languages were chosen as lengua general. 
Moreover, it seems that many local peoples were speaking a related language (i.e. languages of what was to become identified as the Arawak language family [Gilij 1780-1784]). This complex situation may have led to simplification (in the formation of the lingua franca), to koineization (as most non-native speakers were speaking relating languages or dialects) but also to substrate influence (from larger groups of unrelated languages).

To sum up, Mojeño was in contact with numerous indigenous languages before the missions, this contact was even closer during the missions and it still goes on nowadays, though counting a more reduced number of languages. Contact with Spanish started in the 17th century, rather loosely at first. It is very intense now that Spanish is the national language and that most indigenous people are heavily acculturated. It is important to note again that the system under study has first been described in 1702, after only four decades of Spanish presence, and two decades of mission life.

\subsection{Borrowing of categories}

Before investigating the borrowing of forms, let us consider which category could have been borrowed from which language.

A first hypothesis is that the non-human category was borrowed from Spanish. There are two rather strong arguments against the hypothesis that Spanish neuter could have influenced the emergence of the non-human category in Mojeño. The first one is that the Jesuits had entered in the region for around three decades only when the Jesuit missionary Marbán wrote the Mojeño grammar in 1701, and we know that Spanish was then little used in the missions. The second one is that the "neuter" is not frequently used in Spanish, where it has only a very weak morphosyntactic value. Spanish has a two-way gender system marking feminine and masculine on some nouns, some adjectives, the past participles and the demonstrative adjectives. Only third person pronouns, demonstrative pronouns, and articles show a third category called neuter, but with a use restricted to denote indeterminate elements, speech content, or to replace a nominal predicate (Gómez Torrego [1997] 2007). This was already the case in Medieval and Classical Spanish (Inés Fernandez Ordóñez, p.c.).

A second hypothesis is that the system of speaker gender indexicality was borrowed. In the region, Bésiro (also known as Chiquitano) is well-known for having such a system (Borges 2000; Falkinger 2002). The Bésiro people has been in contact with some Arawak people in the 16th and 17th century, before the missions period (Vincent Hirtzel, p.c.). In Bésiro, the locus of gender indexicality is more complex than in Mojeño. Gender indexicality in Bésiro is precisely found in the marking of grammatical gender. For male speakers, only the masculine is 
marked, with the suffix - $t i$ in the singular (23) and - $m a$ in the plural. Female speakers make no gender distinctions (24).

$\begin{array}{ll}\text { ba-páche-ro=ti } & n \text {-i-kisé-s } \\ \text { 3-look_for-TAM=3SG.M }{ }^{\Uparrow} & \text { N-3-knife-DET }\end{array}$

(Bésiro, Pierric Sans, p.c.)

'He looks for her knife.'

(24) ba-páche-ro n-i-kisé-s

3-look_for-TAM N-3-knife-DET

i. 'He/she looks for his/her knife.' o

ii. 'She looks for her knife.' $\hat{\jmath}$

Bésiro's gender indexicality system is not completely comparable to that of Mojeño. We could yet hypothesize that the distinction of gender of the speaker is borrowable, although this has never been discussed to date.

Also, it seems unlikely that the unspecified third person category was borrowed into a language with an already quite elaborate paradigm including third person specific categories with gender and number distinctions.

\subsection{Borrowing of forms}

This section discusses four possible external sources for some Mojeño innovated forms.

Firstly, it could be conceivable that the Spanish neuter demonstrative pronoun esto be a source for the non-human third person pronoun eto (and its possible Paunaka cognate chy-). The borrowed independent pronoun would then have extended to all other pronominal paradigms (with or without the initial $e$, depending on the sets) by analogy with other third person forms. ${ }^{19}$ In the event that this hypothesis would prove correct, the homonymy with the numeral "one" would still have to be explained. As mentioned in Section 4.1, borrowing from Spanish seems implausible because of the low degree of contact. Moreover, it presupposes a dubious extension from neuter to non-human.

Secondly, it is tempting to compare the two suffixes specific to Béstro male spea-

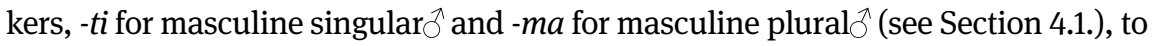
Mojeño ti (unspecified third person) and ma (masculine singular ${ }^{\gamma}$ ). However, the translations do not fit in the case of $t i$, and the singular/plural switch seems unlikely in the case of ma (although Mojeño ma has a plural meaning in the non-human

19 In the formation of the demonstrative, it would first have been in competition with jo in Old Mojeño, but not have been maintained up to the modern dialects. 
demonstrative). Moreover, when one observes the integration of these person markers into the person marking system, they seem rather well integrated in the Mojeño system, while they look like an "addition" in the Bésiro system. In Mojeño, $m a$ and $t i$ have typical properties of person markers (cf. Section 2.2): the CV shape, the position and their functions (except that $t i$ has restricted functions). In Bésiro, masculine is a category used only in the male speech, in addition to the basic forms used by females. The enclitic status of the masculine markers is distinct from that of other person markers that are prefixed to nouns and verbs, or suffixed in a different position, as far as a third person possessor is concerned. Thus, if some borrowing had occurred, Bésiro would be the target, rather than the source, of the borrowing.

Thirdly, there is a demonstrative $m a$ in the Tacanan languages Ese Ejja and Araona, spoken in Northwest Bolivia (to the west of the Mojeño area). According to Lathrap (1970), Takanan groups would have initially lived in Eastern Bolivia (Vuillermet 2012: 38).$^{20}$ Ese Ejja $m a$ tends to refer to things outside the speech act situation (Vuillermet 2012: 356). Araona $m a$ is used for elements visible by the speaker and close to him/her (Emkow 2006: 292). If an Ese Ejja or Araona ma was borrowed at some stage into Mojeño, its meaning became restricted to a singular masculine third person and only male speakers must have used it without further diffusion to the whole speech community. This hypothesis will be discussed in Section 4.3.

Fourthly, the four Mataguayan languages (Wichi, Chorote, Nivacle and Maka) spoken in the Argentinan, Paraguayan and Bolivian Chaco show an indefinite subject prefix $t i-\sim t j$ - (Alain Fabre p.c.). TheZamucoan languages Ayoreo and Chamacoco show some $t-\sim t i-\sim t j i$ - third person prefixes. The contact history between Arawak populations and peoples from the Chaco has not been fully investigated, but some influences have been asserted (Combès 2010). This hypothesis calls for further historical and linguistic investigation.

To summarize, there were several possible sources for the Mojeño innovative forms:

- Spanish neuter demonstrative esto for the non-human form to.

- Bésiro masculine singular and plural suffixes - $t i$ and - $m a$ for the unspecified $t i$ and the masculine singular ma forms.

- Ese Ejja or Araona demonstrative $m a$ for the masculine singular $m a$ form.

- Mataguayan indefinite $t i$ - for the unspecified third person $t i$ - prefix.

20 Alexiades and Peluso (2003) suggest that the settlement of the Jesuits mission in the late 17th century could have triggered a migration of the Takanan groups westwards in the direction of their present location. 
The first two hypothesis were rejected, while the last two are still highly speculative in absence of more information on the contact situation and more evidence for the borrowing process.

\subsection{Emergence of categories via language mixture}

Island Carib is well-known for being a mixed language, with many elements from Carib entering an Arawak language after some Carib men came to live among an Arawak group, maybe limited to women (Taylor and Hoff 1980). Both Island Carib and its offspring Garifuna have a male versus female speech distinction. The male/female suppletive forms can be explained by different sources, in particular in the pronominal system:

$$
\begin{aligned}
& \text { a) -aú (from Carib) } \\
& 15 \mathrm{~s} \mathrm{O}^{\top} \\
& \text { b) nuguya (from Arawak) } \\
& 1 \mathrm{SG} \text { ㅇ }
\end{aligned}
$$

(Garifuna, de Pury 2003)

To use the terminology of contact linguistics, no category has been borrowed in this process, because, for instance, 1SG previously existed in the local Arawak language, and 15G ${ }^{\lambda}$ is not a category of Carib: the alternation between the two pronominal forms results in the first place from a mixture of two sources distributed according to the linguistic origin of the speaker. In a second step, the distinction crystallized on the gender of the speaker. This led to the creation of a new distinction (male versus female speaker). As a result, where one category existed formerly in the two source languages (e.g. 1SG), now there exist two, viz. $1 \mathrm{SG}^{\lambda}$ and $1 \mathrm{SG}^{\mathrm{O}}$ in Island Carib, without either one having been borrowed. Contact led to pattern innovation.

The explanation of language mixture as an origin of speaker gender indexicality has further been applied to other languages with gender indexicality, such as Kokama (Cabral 1995) or Karajá (Rodrigues 2004). As a result, gender indexicality is commonly associated with mixed languages or catastrophic contact situations. While I agree that gender indexicality may be caused by contact in languages like Island Carib whose genesis involves some language mixture, gender indexicality is far from being as pervasive as it is in Island Carib in most of the languages with a male/female speech distinction reviewed in Rose (2013c). For example, it occurs mainly in interjections in the Tupi-Guarani languages, and in just two words in Xavante (Machado Estevam 2011: 17). In languages, like Mojeño, where the distinction affects pronominal forms, it can be restricted to very few but frequent 
morphemes (as it happens, it affects only the third person human masculine singular in Mojeño). Island Carib is a well-known case of gender indexicality in the Americas, but it is not representative of the phenomenon. Gender indexicality is very heterogeneous, and its genesis is also probably varied. Specific studies on gender indexicality in Karajá (Ribeiro 2012) and Basque (Alberdi 1995) have shown that it was due to internal development.

In Mojeño as well, the $\delta / P$ distinction could have emerged through language mixture. Marbán's (1702) description of late 17th century Mojeño does not suggest that gender indexicality is anything recent and unstable. It is likely that it emerged earlier. It is known that the region was showing a great linguistic diversity, but the historical information is probably too scarce to suggest a specific scenario (Hirtzel and Daillant 2012). Mixture with some Tacanan language is highly speculative but two historical scenarios deserve to be considered: either a large group of Mojeño men borrowed the morpheme from a Takanan group they were in close contact with, or a large group of Takanan men brought it, as part of a substrate, into the language of a Mojeño group they lived with. In both scenarios, this form would have become emblematic of manhood and extended to other likely existing male Mojeño speakers. Crystallization of the correlation between linguistic forms and speakers' origin into gender indexicality would explain the absence of diffusion of the $m a$ form to the female Mojeño speakers. These scenarios are highly speculative, because they are based on scarce historical evidence, but yet plausible as attested by the history of Island Carib (see Section 4.3).

To sum up, Section 4 investigated the possible role of contact in the development of some Mojeño third person categories. It considered three possibilities: that contact with Spanish or other indigenous languages have led to the borrowing of categories, to the borrowing of forms, to the creation of a new distinction from multiple language sources. Several hypotheses have been put forward. However, no solid linguistic nor socio-historical arguments have been found to confirm these hypotheses. This section underlines, as a methodological conclusion, the difficulty to find substantive arguments regarding contact-induced evolution, in absence of solid descriptions of past socio-historical contacts.

\section{Conclusion}

Mojeño displays a very rich pronominal paradigm, with seven sub-categories of the third person. It indexes, among others, an uncommon distinction, namely that of the gender of the speaker. Reconstructions of Proto-Arawak explain threeto-five forms for the third person. Thus, Mojeño has innovated two to three of these categories: the non-human, the unspecified third person form, and, within 
the third person masculine, the distinctive indexicality of male versus female speakers. These innovations led to a complete reorganization of the third person category.

This paper has investigated the possible sources of this increase in complexity, both considering the language internal development and external influences. To pursue this issue, different sets of data have been carefully examined. These are data of three varieties of Mojeño (Old Mojeño, Ignaciano, Trinitario); suggested reconstructions for Proto-Arawak; data from sister Southern Arawak languages, and data from other languages spoken in the area, such as Spanish and the indigenous Béstro and Ese Ejja. Several hypotheses have been issued, some in terms of internal development and others in terms of contact-induced changes. Within contact-induced changes, three different types of processes have been considered: borrowing of categories, borrowing of forms, and creation of a category via multiple language sources. Unfortunately, no clear linguistic nor socio-historical data helps to assert a clear genesis for the Mojeño innovative forms/categories. Hopefully this will be solved in the future thanks to a better knowledge of closely related languages, both historically and geographically. The paper shows very clearly how difficult it can be to disentangle internal and external developments. It stresses the necessity for contact linguistics to study a contact situation in detail and balance all possible factors of evolution.

\section{Acknowledgments}

I would like to thank the editors of this volume and Brigitte Pakendorf for their careful reviews.

\section{Abbreviations}

$\begin{array}{ll}\text { + } & \text { female speaker } \\ \text { J } & \text { male speaker } \\ 1 & \text { first person } \\ 2 & \text { second person } \\ 3 & \text { third person } \\ \text { ACT } & \text { active } \\ \text { ART } & \text { article } \\ \text { CLF } & \text { classifier } \\ \text { DEM } & \text { demonstrative } \\ \text { DET } & \text { determiner }\end{array}$




$\begin{array}{ll}\text { DIM } & \text { diminutive } \\ \text { DIS } & \text { distal } \\ \text { F } & \text { feminine (human singular) } \\ \text { FUT } & \text { future } \\ \text { HUM } & \text { human } \\ \text { INDEF } & \text { indefinite } \\ \text { M } & \text { masculine (human singular) } \\ \text { N } & \text { nominal prefix } \\ \text { NH } & \text { non-human } \\ \text { NUM } & \text { numeral marker } \\ \text { PERF } & \text { perfective } \\ \text { PL } & \text { plural } \\ \text { PROX } & \text { proximal } \\ \text { SG } & \text { singular } \\ \text { TAM } & \text { tense aspect mood }\end{array}$

\section{References}

Aikhenvald, Alexandra Y. 1995. Person marking and discourse in North Arawak languages. Studia Linguistica 49(2). 152-195.

Aikhenvald, Alexandra Y. 1999. The Arawak language family. In R. M. W. Dixon \& Alexandra Y. Aikhenvald (eds.), The Amazonian languages, 65-106. Cambridge: Cambridge University Press.

Aikhenvald, Alexandra Y. 2002. Language contact in Amazonia. Oxford: Oxford University Press. Alberdi, Jabier. 1995. The development of the Basque system of terms of address and the allocutive conjugation. In José Ignacio Hualde, Joseba A. Lakarra \& R. L. Trask (eds.), Towards a history of the Basque language, 279-293. Amsterdam \& Philadelphia: John Benjamins.

Alexiades, Miguel \& Daniela Peluso. 2003. La sociedad ese eja: una aproximación histórica a sus orígenes, distribución, asentamiento y subsistencia. In C. Huertas \& A. García (eds.), Los pueblos indígenas de Madre de Dios: Historia, etnografía y coyuntura, 91-110. Lima: IWGIA.

Bhat, D. N. 2004. Pronouns. Oxford \& New York: Oxford University Press.

Borges, Mônica Veloso. 2000. 0 fenômeno da diferenciação entre as falas feminina e masculina em línguas indígenas. Revista do Museu Antropológico, Goiânia 3/4(1). 75-103.

Cabral, Ana Suelly. 1995. Contact-induced language change in the western amazon: The non-genetic origin of the Kokama language. Pittsburg: University of Pittsburg PhD dissertation.

Combès, Isabelle. 2010. ¿Indios y blancos? Hacer (etno) historia en las tierras bajas de Bolivia. Boletín Americanista 60.15-32.

Danielsen, Swintha. 2007. Baure: An Arawak language of Bolivia. Leiden: CNWS.

Danielsen, Swintha. 2011. The personal paradigms in Baure and other Southern Arawakan languages. International Journal of American Linguistics 77(4). 495-520. 
Danielsen, Swintha \& Tania Granadillo. 2008. Agreement in two Arawak languages: Baure and Kurripako. In Mark Donohue \& Søren Wichmann (eds.), The typology of semantic alignment, 396-411. Oxford: Oxford University Press.

de Pury, Sybille. 2001. Le garifuna, une langue mixte. Faits de Langues 19. 75-84.

de Pury, Sybille. 2003. “Vice-versa”. Le genre en garifuna. Faits de Langues 21(2). 155-162.

Dixon, R. M. W. 1997. The rise and fall of languages. Cambridge: Cambridge University Press.

Emkow, Carola. 2006. A grammar of Araona, an Amazonian language of Northwestern Bolivia. Melbourne: LaTrobe University PhD dissertation.

Falkinger, Sieglinde. 2002. Diferencias entre el lenguage de hombres u mujeres en Chiquitano (Besiro). In Mily Crevels, Simon van de Kerke, Sérgio Meira \& Hein van der Voort (eds.), Current studies on South American languages, 43-56. Leiden: CNWS.

Fleming, Luke. 2012. Gender indexicality in the Native Americas: Contributions to the typology of social indexicality. Language in Society 41(3). 295-320.

Gilij, Filippo Salvatore. 1780-1784. Saggio di Storia Americana, o sia, Storia Naturale, Civile a Sacra de'Regni e delle Provinzia Spagnuole di Terra-Ferma nell'America Meridionale, 4 vols. Rome: L. perego erede Salvioni.

Gómez Torrego, Leonardo. 2007 [1997]. Gramática didáctica del español. Madrid: SM.

Greenberg, Joseph. 1978. How does a language acquire gender markers? In Joseph Greenberg, Charles A. Ferguson \& Edith A. Moravcsik (eds.), Universals of human language, vol. 3: Word structure, 47-82. Stanford: Stanford University Press.

Heine, Bernd \& Tania Kuteva. 2002. World lexicon of grammaticalization. Cambridge: Cambridge University Press.

Heine, Bernd \& Tania Kuteva. 2006. The changing languages of Europe. Oxford: Oxford University Press.

Heine, Bernd \& Kyung-An Song. 2010. On the genesis of personal pronouns: Some conceptual sources. Language and Cognition 2(1). 117-147.

Heine, Bernd \& Kyung-An Song. 2011. On the grammaticalization of personal pronouns. Journal of Linguistics 47(3). 587-630.

Hirtzel, Vincent \& Isabelle Daillant. 2012. Los arawak del Mamoré y su politie al amanecer de las misiones jesuitas. Paper presented at 54th International Congress of Americanists, Symposium "Arawakan linguistic and cultural identities", Vienna.

Lathrap, Donald Ward. 1970. The Upper Amazon. London: Thames \& Hudson.

Machado Estevam, Adriana. 2011. Morphosyntaxe du Xavante. Paris: Université Paris Diderot (Paris 7) PhD dissertation.

Marbán, Pedro. 1702. Arte de la lengua Moxa, con su vocabulario, y cathecismo. Lima: Imprenta Real de Joseph de Contreras.

Marbán, Pedro. 1975 [1702]. Cathecismo en lengua española y moxa. Vaduz-Georgetown: Cabildo.

Matras, Yaron. 2009. Language contact. Cambridge: Cambridge University Press.

Mithun, Marianne. 2012. Morphologies in contact: Form, meaning, and use in the grammar of reference. In Martine Vanhove, Thomas Stolz, Aina Urdze \& Hitomi Otsuka (eds.), Morphologies in contact, 15-36. Berlin: Akademie Verlag.

Mujica, Mitzila Isabel Ortega. 1992. Aspectos fonológicos e gramaticais da língua Yawalapiti (Aruak). Campinas: Universidade Estadual de Campinas dissertation.

Olza Zubiri, Jesús, C. Nuni de Chapi \& J. Tube. 2002. Gramática Moja Ignaciana. Caracas: Universidad Catolica Andres Bello.

Payne, David. 1987. Some morphological elements of Maipuran Arawakan: Agreement affixes and the genitive construction. Language Sciences 9(1). 57-75. 
Payne, David. 1991. A classification of Maipuran (Arawakan) languages based on shared lexical retentions. In Desmond C. Derbyshire \& Geoffrey K. Pullum (eds.), Handbook of Amazonian languages, vol. 3, 355-499. Berlin: Mouton de Gruyter.

Ribeiro, Eduardo. 2012. A grammar of Karajá. Chicago: Chicago University PhD dissertation.

Rodrigues, Aryon. 2004. Sobre a possível origem da diferença fonética entre a fala masculina e a feminina em Karajá. Llames 4. 115-121.

Rose, Françoise. 2008. The word-prosodic system of Mojeño Trinitario and pervasive vowel deletion. Paper presented at A Estrutura de Línguas Amazônicas: Fonologia e Gramática II, Recife.

Rose, Françoise. 2011a. Competition between finite and non-finite nominalizations in Mojeño Trinitario. Paper presented at Séminaire du PICS Complexité Syntaxique et Diversité Typologique, Paris.

Rose, Françoise. 2011b. Who is the third person? Fluid transitivity in Mojeño Trinitario. International Journal of American Linguistics 77(4). 469-494.

Rose, Françoise. 2013a. The emergence of articles in Mojeño. Paper presented at Workshop on Languages with and without articles, Paris.

Rose, Françoise. 2013b. Le genre du locuteur et de l'allocutaire dans les systèmes pronominaux: genre grammatical et indexicalité du genre. Bulletin de la Société de Linguistique de Paris 108(1). 381-417.

Rose, Françoise. 2013c. Les distinctions de parler entre hommes et femmes en Amérique du Sud. Paper presented at Société de Linguistique de Paris.

Rose, Françoise. 2013d. Los generolectos del mojeño. Liames 13. 115-134.

Rose, Françoise. 2014. When vowel deletion blurs reduplication in Mojeño Trinitario. In Gale Goodwin Gómez \& Hein van der Voort (eds.), Reduplication in South-American languages, 375-399. Leiden \& Boston: Brill.

Rose, Françoise. in press. Mojeño Trinitario. In Mily Crevels and Peter Muysken (eds.), Lenguas de Bolivia, vol 3. Oriente. La Paz: Plural Editores.

Saito, Akira. 2009. "Fighting against a hydra”: Jesuit Language Policy in Moxos. In Shinzo Kawamura \& Cyril Veliath (eds.), Beyond the borders: Global perspective of Jesuit mission history, 350-363. Tokyo: Sophia University Press.

Siewierska, Anna. 2004. Person. Cambridge: Cambridge University Press.

Silverstein, Michael. 1985. Language and the culture of gender: At the intersection of structure, usage, and ideology. In Elizabeth Mertz \& Richard Parmentier (eds.), Semiotic mediation: Sociocultural and psychological perspectives, 219-259. Orlando: Academic Press.

Taylor, Douglas \& Berend Hoff. 1980. The linguistic repertory of the Island-Carib in the seventeeth century: The men's language - A Carib pidgin? International Journal of American Linguistics 46(4). 301-312.

Thomason, Sarah G. \& Daniel L. Everett. 2001. Pronoun borrowing. In Charles Chang, Michael J. Houser, Yuni Kim, David Mortensen, Mischa Park-Doob \& Maziar Toosarvandani (eds.), Proceedings of the Annual Meeting of the Berkeley Linguistics Society 27. 301-315. Berkeley: Berkeley Linguistics Society.

Vuillermet, Marine. 2012. A grammar of Ese Ejja, a Takanan language of the Bolivian Amazon. Lyon: Université Lumière Lyon $2 \mathrm{PhD}$ dissertation.

Wallace, Stephen. 1983. Pronouns in contact. In Frederick Browning Agard, Gerald Kelley, Adam Makkai \& Valerie Becker Makkai (eds.), Essays in honor of Charles F. Hockett, 573-589. Leiden: Brill.

Witzlack-Makarevich, Alena, Taras Zakharko, Lennart Bierkandt, Fernando Zúñiga \& Balthasar Bickel. 2011. Decomposing hierarchical alignment: Co-arguments as conditions on alignment. Paper presented at 44th Annual Meeting of the Societas Linguistica Europaea, Universidad de la Rioja, Logroño, Spain. 


\section{Appendix A}

Sets of person markers with variants in Old Mojeño (OM), Mojeño Ignaciano (MI) and Mojeño Trinitario (MT)

\begin{tabular}{|c|c|c|c|c|c|c|c|c|c|}
\hline & Pronouns & \multicolumn{2}{|c|}{ Articles } & \multicolumn{2}{|c|}{ DEM roots } & \multicolumn{2}{|c|}{ Prefixes } & \multicolumn{2}{|c|}{ Suffixes } \\
\hline $1 \mathrm{SG}$ & nuti & & & & & $\begin{array}{l}n u- \\
n u- \\
n-\end{array}$ & $\begin{array}{l}\text { OM } \\
\text { MI } \\
\text { MT }\end{array}$ & $-n u$ & \\
\hline $2 \mathrm{SG}$ & piti & & & & & $\begin{array}{l}p i- \\
p i- \\
p-\end{array}$ & $\begin{array}{l}\text { OM } \\
\text { MI } \\
\text { MT }\end{array}$ & $-v i$ & \\
\hline $1 \mathrm{PL}$ & viti & & & & & $\begin{array}{l}v i- \\
v i- \\
v-\end{array}$ & $\begin{array}{l}\text { OM } \\
\text { MI } \\
\text { MT }\end{array}$ & $\begin{array}{l}\text {-avi } \\
\text {-havi } \\
\text {-ovi }\end{array}$ & $\begin{array}{l}\text { OM } \\
\text { MI } \\
\text { MT }\end{array}$ \\
\hline $2 \mathrm{PL}$ & $e t i$ & & & & & $\begin{array}{l}e- \\
e- \\
i / a / \varnothing\end{array}$ & $\begin{array}{l}\text { OM } \\
\text { MI } \\
\text { MT }\end{array}$ & -'e & \\
\hline $3 M{ }^{\lambda}$ & ema & $\begin{array}{l}\text { (e)ma } \\
m a\end{array}$ & $\begin{array}{l}\text { MI } \\
\text { MT }\end{array}$ & $m a$ & & ma- & & & \\
\hline $3 \mathbf{M}_{+}$ & $e \tilde{n} i$ & $\begin{array}{l}(e) \tilde{n} i \\
\tilde{n} i\end{array}$ & $\begin{array}{l}\text { MI } \\
\text { MT }\end{array}$ & $\tilde{n} i$ & & $\tilde{n} i-$ & & & \\
\hline $3 F$ & esu & $\begin{array}{l}(e) s u \\
s u\end{array}$ & $\begin{array}{l}\text { MI } \\
\text { MT }\end{array}$ & su & & $\begin{array}{l}\text { su- } \\
\text { su- } \\
\text { s- }\end{array}$ & $\begin{array}{l}\text { OM } \\
\text { MI } \\
\text { MT }\end{array}$ & & \\
\hline $3 P L$ & $\begin{array}{ll}\text { eno } & \mathrm{OM} \\
\text { ena } & \mathrm{MI} \\
\text { eno } & \mathrm{MT}\end{array}$ & $\begin{array}{l}\text { (e)na } \\
\text { no }\end{array}$ & $\begin{array}{l}\text { MI } \\
\text { MT }\end{array}$ & $\begin{array}{l}\text { no } \\
\text { na } \\
\text { no }\end{array}$ & $\begin{array}{l}\text { OM } \\
\text { MI } \\
\text { MT }\end{array}$ & $n a-$ & & & \\
\hline $3 \mathrm{NH}$ & $\begin{array}{ll}\text { eto } & \mathrm{OM} \\
\text { eta } & \mathrm{MI} \\
\text { eto } & \mathrm{MT}\end{array}$ & $\begin{array}{l}\text { (e)ta } \\
\text { to }\end{array}$ & $\begin{array}{l}\text { MI } \\
\text { MT }\end{array}$ & $\begin{array}{l}j o \\
j V \\
j o(\mathrm{SG}) \\
m a(P L)\end{array}$ & $\begin{array}{l}\text { OM } \\
\text { MI } \\
\text { MT } \\
\text { MT }\end{array}$ & ta- & & & \\
\hline 3 & & & & & & $\begin{array}{l}t i- \\
t i- \\
t(y)-\end{array}$ & $\begin{array}{l}\text { OM } \\
\text { MI } \\
\text { MT }\end{array}$ & & \\
\hline "other" & & & & & & $\begin{array}{l}\text { opo- } \\
\text { apa- } \\
\text { 'po- }\end{array}$ & $\begin{array}{l}\text { OM } \\
\text { MI } \\
\text { MT }\end{array}$ & & \\
\hline
\end{tabular}


Brought to you by | De Gruyter / TCS Authenticated

Download Date | 11/24/14 6:12 PM 